\title{
Definition and diagnosis of small fiber neuropathy: consensus from the Peripheral Neuropathy Scientific Department of the Brazilian Academy of Neurology
}

\author{
Definição e diagnóstico de neuropatia de fibras finas: consenso do Departamento \\ Científico de Neuropatias Periféricas da Academia Brasileira de Neurologia.
}

Francisco de Assis Aquino Gondim¹, Amilton Antunes Barreira², Rinaldo Claudino³, Márcia Waddington Cruz Francisco Marcos Bezerra da Cunha ${ }^{5}$, Marcos Raimundo Gomes de Freitas ${ }^{6}$, Marcondes Cavalcante França $\mathrm{Jr}^{7}$, Marcus Vinícius Magno Gonçalves ${ }^{8}$, Wilson Marques $\mathrm{Jr}^{2}$, Osvaldo José Moreira Nascimento ${ }^{6}$, Acary Souza Bulle Oliveira ${ }^{9}$, Raquel Campos Pereira ${ }^{10}$, Camila Pupe ${ }^{6}$, Francisco Tellechea Rotta ${ }^{11}$, Pedro Schestatsky ${ }^{11}$

\begin{abstract}
The aim of this study was to describe the results of a Brazilian Consensus on Small Fiber Neuropathy (SFN). Fifteen neurologists (members of the Brazilian Academy of Neurology) reviewed a preliminary draft. Eleven panelists got together in the city of Fortaleza to discuss and finish the text for the manuscript submission. Small fiber neuropathy can be defined as a subtype of neuropathy characterized by selective involvement of unmyelinated or thinly myelinated sensory fibers. Its clinical picture includes both negative and positive manifestations: sensory (pain/ dysesthesias/pruritus) or combined sensory and autonomic complaints, associated with an almost entirely normal neurological examination. Standard electromyography is normal. A growing list of medical conditions is associated with SFN. The classification of SFN may also serve as a useful terminology to uncover minor discrepancies in the normal values from different neurophysiology laboratories. Several techniques may disclose sensory and/or autonomic impairment. Further studies are necessary to refine these techniques and develop specific therapies.
\end{abstract}

Keywords: small fiber neuropathy; unmyelinated nerve fibers.

\begin{abstract}
RESUMO
O objetivo deste estudo é descrever os resultados de um Consenso Brasileiro sobre Neuropatia de Fibras Finas (NFF). Quinze neurologistas (membros da Academia Brasileira de Neurologia) revisaram uma versão preliminar do artigo. Onze panelistas se reuniram na cidade de Fortaleza para discutir e terminar o texto para a submissão do manuscrito. NFF pode ser definida como um subtipo de neuropatia caracterizada pelo envolvimento seletivo de fibras sensitivas amielínicas ou pouco mielinizadas. Seu quadro clínico inclui manifestações negativas e positivas: sensitivas (dor/disestesias/prurido) ou queixas sensitivas e autonômicas combinadas, associadas a exame neurológico quase totalmente normal.A eletromiografia convencional é normal. Uma lista crescente de condições médicas causa NFF. NFF também pode servir como uma terminologia útil para referenciar pequenas discrepâncias nos valores normais de diferentes laboratórios de neurofisiologia. Diferentes técnicas podem evidenciar anormalidades sensitivas e/ou autonômicas. São necessários mais estudos para refiná-las e para o desenvolvimento de terapias específicas.
\end{abstract}

Palavras-chave: neuropatia de pequenas fibras; fibras nervosas amielínicas.

\footnotetext{
'Universidade Federal do Ceará, Faculdade de Medicina, Hospital Universitário Walter Cantídio, Fortaleza CE, Brasil;

2Universidade de São Paulo, Faculdade de Medicina de Ribeirão Preto, Departamento de Neurociências e Hospital das Clínicas, Ribeirão Preto SP, Brasil;

${ }^{3}$ Universidade Federal de Santa Catarina, Florianópolis, SC, Brasil;

«Universidade Federal do Rio de Janeiro, Departamento de Neurologia, Rio de Janeiro RJ, Brasil;

${ }^{5}$ Universidade Federal do Cariri, Barbalha CE, Brasil;

${ }^{6}$ Universidade Federal Fluminense, Faculdade de Medicina, Departamento de Neurologia, Niterói RJ, Brasil;

ZUniversidade de Campinas, Departamento de Neurologia, Campinas SP, Brasil;

¿Universidade da Região de Joinville, Joinville SC, Brasil;

IUniversidade Federal de São Paulo, Departamento de Neurologia, São Paulo SP, Brasil;

10Universidade Federal de Uberlândia, Faculdade de Medicina, Uberlândia MG, Brasil;

${ }^{11}$ Hospital Moinhos de Vento, Porto Alegre RS, Brasil.

*All authors are members, and produced this manuscript on behalf of the Scientific Department of Peripheral Neuropathy, Brazilian Academy of Neurology Correspondence: Francisco de Assis Aquino Gondim; Serviço de Neurologia, Departamento de Medicina Clínica da UFCE; Rua Capitão Francisco Pedro, 1290 ; 60430-372 Fortaleza CE, Brasil; E-mail: gondimfranc@gmail.com

Conflict of interest: There is no conflict of interest to declare.

Received 19 December 2017; Accepted 15 January 2018
} 
Neuropathy is a common product of several medical conditions. Peripheral nerves may be damaged by a wide range of mechanisms, including metabolic, infectious, nutritional, vascular, genetic and auto-immune disorders. Single nerve damage is called mononeuropathy, while patchy, combined but noncontiguous (non-length dependent) nerve involvement is called mononeuropathy multiplex. When peripheral nerves are affected symmetrically (usually in a length-dependent fashion), the disease process is called polyneuropathy. In addition to the topographical distribution, neuropathies may be classified according to several characteristics, among them the subset of nerve fibers involved.

A very particular group of peripheral neuropathies is the one due to selective involvement of small fibers, the so-called "small fiber neuropathies" (SFN). Despite a major recent interest in SFN, several aspects related to these conditions are still controversial. This assertion can be illustrated by the lack of specific chapters devoted to the discussion of SFN in classic peripheral neuropathy textbooks.

In most instances, unmyelinated or thinly myelinated sensory fibers are affected, but autonomic fibers may be also affected; in this case accompanied by autonomic manifestations. Rarely, neuropathies may involve only fibers devoted to autonomic functions (autonomic neuropathies). Those conditions are usually considered as a particular group and will not be included in this consensus. The aim of this study was to summarize the results of a Consensus from the Scientific Department of Peripheral Neuropathies of the Brazilian Academy of Neurology, which was designed to define and diagnose SFN. Part of it has been reported in abstract form elsewhere ${ }^{1}$.

\section{METHODS}

After identifying the need to generate a text to discuss the definition and methodology for the diagnosis of SFN, a group of 15 Brazilian neurologists, members of the Peripheral Neuropathy Scientific Department of the Brazilian Academy of Neurology and considered to be representative experts on the subject, was formed.

The first author produced a draft summarizing the main views on the subject and emailed the text to 12 other specialists. This number was subsequently increased to 15 , since two participants informed that they were not going to attend the face-to-face meeting. Each participant reviewed the whole text, and was also responsible for focusing his/ her review on a specific topic. A preliminary review was emailed by each participant to the coordinator and a second text was emailed to the panelists. After four months, 11 panelists got together in the city of Fortaleza to discuss the controversial points and vote for the final text of the recommendations. Four original panelists could not attend the face-to-face meeting, but since they had collaborated by email and Internet discussion, and agreed with the final text, the total number of participants remained at 15 . In addition to the main text, each participant received (by email) a list of papers generated by a PubMed search using the key words "small fiber/fibre neuropathy", comprising a total of 1,235 papers (search conducted on 2/3/2017).

\section{RESULTS}

\section{Anatomical considerations}

Peripheral nerves are formed by parallel bundles (fascicles) embedded in a collagenous matrix (epineurium). Each fascicle is separated by a perineural sheath formed by flattened squamous cells connected by tight junctions (perineurium). The individual motor, sensory and autonomic nerve fiber (axon and its associated Schwann cells) is enveloped by connective tissue (endoneurium), although some authors include the Schwann cells and axons as part of the endoneurium $^{2}$. In addition to different functional subtypes (motor, sensory and autonomic), axons can also be distinguished by different degrees of myelination, being highly, moderately, or thinly myelinated (A $\delta$ fibers), or completely lacking a myelin envelope, the so-called unmyelinated fibers.

Unmyelinated fibers (type C) can be autonomic or sensory. They are surrounded by Schwann cells in a different way, forming the so-called Remak fibers. In 1838, Remak teased autonomic nerve fibers in water and differentiated myelinated (tubuli primitivi) from unmyelinated fibers fibrae organicae ${ }^{3}$. In 1868, Langerhans described the intraepidermal nerve fiber endings ${ }^{4}$. Sixty years later, Remak and Tuckett identified both Schwann cells and axons ${ }^{3}$. Joseph Erlanger and Herbert Spencer Gasser won the Nobel Prize in 1944 for their studies on the differential functions of single nerve fibers. Unmyelinated axons range in diameter from $0.2 \mu \mathrm{m}$ to $3 \mu \mathrm{m}$ and in men there are 1-4 axons per Schwann cell unit ${ }^{3}$. The proportion of myelinated to unmyelinated fibers in the sural nerve is $1: 4^{5}$. The presence of myelin in very thin fibers does not increase the conduction speed and its absence makes unmyelinated fibers more resistant to metabolic insults ${ }^{3}$. On the other hand, since unmyelinated fibers are not insulated from each other, impulses conducting in one axon may spread to neighboring axons ${ }^{3}$.

New histological evidence from skin biopsies completely changed the concept of SFN, as it revealed that axons lose the Schwann cell ensheathment as they cross the dermalepidermal junction ${ }^{6}$. However, since the loss of distal nerve endings may indicate the loss of distal fibers from more prominently myelinated sensory fibers, distal nerve fiber loss may be due to a less specific sensory involvement, which could include myelinated sensory fibers (e.g. mediating vibration and proprioception) amenable to assessment by electromyography. This controversial aspect will be discussed further in the next sections. 


\section{Definition and clinical subtypes of small}

fiber neuropathy

The term "small fiber neuropathy" was first employed by Stewart et al. ${ }^{7}$ From the clinical point of view, SFN is defined as a syndrome characterized by sensory or combined sensory and autonomic manifestations, associated with an almost entirely normal neurological examination (except for possible distal pinprick and thermal loss) or at least abnormalities solely associated with small fiber involvement (e.g. orthostatic hypotension).

Small fiber neuropathy may present as negative and positive manifestations. For the sensory subtype of SFN, positive manifestations usually dominate the clinical picture. Patients may complain of dysesthesias, burning, stinging, tingling sensations and neuropathic pain (length-dependent), usually more severe in the evening. Additional complaints include formication-like phenomena and chronic pruritus ${ }^{8}$. Patchy or non-length dependent symptoms have also been described.

The exclusive autonomic subtype has a broader range of manifestations, that can be easily mimicked by several other medical conditions, such as dizziness (due to orthostatic intolerance or orthostatic hypotension), syncopal spells, anhidrosis or hyperhidrosis, decreased lacrimation, decreased salivation, important trophic skin changes, changes in bowel habits (constipation or diarrhea) or urinary complaints (polyuria, urinary retention or incontinence), among others (for a more extensive review of autonomic manifestations, the reader is referred to authoritative texts on autonomic diseases). Although they technically belong to the same group of SFN, autonomic neuropathies are usually studied separately from sensory SFN. Therefore, the term SFN is usually employed to discuss variants that course with sensory changes (pure or associated with autonomic findings) and herein we follow this same clinical tradition.

A non-length dependent variant of SFN has recently been reported and will not be discussed in detail in this review, but the reader is referred to: Brannagan et al.'; and Khoshnoodi et al. ${ }^{10}$. Conditions, like diabetes mellitus, may be associated with forms of SFN associated with combined sensory and autonomic involvement that seems to be the most prevalent subtype ${ }^{11}$. It is important to highlight, that in addition to unusual clinical symptoms such as formicationlike phenomena and chronic pruritus ${ }^{8}$, SFN may be associated with acute neuropathy symptoms (Guillain-Barré-like syndrome), minimal clinical symptoms (subclinical neuropathy) or other controversial clinical entities, such as restless leg syndrome $e^{4,11}$.

\section{Neurological examination in patients with small fiber neuropathy}

Neurological examination may be normal, usually at the very early onset of the disease, but eventually pain and thermal sensations will decrease in a length-dependent fashion in polyneuropathies, following the nerve territories in multiple mononeuropathies, and in a patchy temperature-dependent fashion in leprosy. A mental status examination is usually normal, cranial nerve involvement (usually mild and late, except for some specific variants) may be present for both sensory (involvement of trigeminal sensory modalities) and autonomic subtypes (pupillary, salivation involvement of IX and X nerves). Motor examination is entirely normal (including reflexes), although hyporeflexia also does not invalidate the diagnosis. Sensory examination can, and frequently does, reveal decreased distal pinprick and temperature sensation (length-dependent fashion). There is no agreement on whether minor distal vibratory involvement is acceptable or not. Autonomic abnormalities may be seen on examination, including changes in skin temperature and color as well as in sweating pattern. Other changes on physical examination may be particular to different subtypes of SFN, such as genetic forms, leprosy, SFN associated with systemic diseases and especially with the range of different autonomic disorders (such as orthostatic hypotension, orthostatic tachycardia). These changes will not be the subject of this consensus.

\section{Epidemiology of small fiber neuropathy}

In the normal population, there is only one study from the Netherlands that reported an incidence of SFN of 11.7 cases per 100,000 population per year, and higher rates in individuals older than 65 years $^{12}$. The overall prevalence of neuropathy is $2.4 \%$ (in those older than 65 years, it may reach $8 \%$ ) and estimates of hereditary neuropathy are as high as 1 in 1,214 persons ${ }^{6}$. In patients with certain types of systemic conditions, SFN can be highly prevalent, e.g. celiac and inflammatory bowel diseases ${ }^{13,14,15}$. Small fiber neuropathy is a common presentation of axonal idiopathic polyneuropathy or cryptogenic sensory polyneuropathy. In a cooperative study involving two North American sites and one South American (Federal Fluminense University in Brazil), cryptogenic sensory polyneuropathy made up $25 \%$ of neuropathy cases ${ }^{16}$.

\section{Electromyography testing}

Nerve conduction parameters can be significantly affected by several physiological factors, such as body temperature, height, age, anatomical variations and anatomical differences. Normal values for the different neurophysiological parameters are not universally accepted. Each neurophysiology laboratory is responsible for setting up the normal values and usually employs a slightly different profile of common neurophysiological techniques. In addition, most neurophysiology laboratories do not have adequate normal values for different age groups. Since most patients undergoing evaluation for peripheral neuropathy have not had prior electrodiagnostic testing, it is also theoretically possible that a given neurophysiological parameter, such as sensory or motor amplitude, may be within the normal range for a certain neurophysiology laboratory but still reflect an unexplained decrease for a given time interval. Therefore, a normal 
nerve conduction study cannot exclude minor large-fiber axonal decrements. This may explain why a patient labeled with SFN may indeed have a minor decrement of distal vibration. In this regard, although not necessarily entirely true for all cases, the current terminology and concept of SFN may serve as an important concept for the diagnosis of peripheral neuropathy itself and avoid confusion (labeling a patient with symptomatic neuropathy as normal because of normal EMG results) generated by diverse neurophysiological sets of normal values within the laboratory tests.

\section{Mechanisms of selective small fiber involvement}

Although, most commonly, all types of peripheral axons (motor, sensory and autonomic) are affected by a specific pathogenic mechanism, different disease processes can lead to more selective involvement of a particular axon subtype, due to variable reasons. Diffuse unmyelinated and thinly myelinated fibers can be affected separately in SFN. The most common site of small fiber involvement is at the distal nerve branches at the skin, although non-length-dependent involvement has been described. Here, we provide a growing list of conditions that can lead to selective small fiber involvement in humans, at least during part of the natural course of the condition

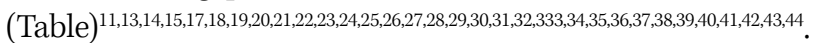

As we discuss in the next sections, pure (isolated) involvement of small nerve fibers may be difficult to pinpoint. Most commonly, at least a milder degree of combined large-fiber involvement is observed, leading us to conclude that, "pure" small fiber involvement is, in several instances, a fallacy. Selective small fiber involvement can only be explained by specific genetic conditions and a few auto-immune disorders, as we will subsequently point out.

\section{Tests to confirm the clinical diagnosis of small fiber neuropathies}

By definition, as large fibers are spared in small fiber neuropathies, the most classic ways to document peripheral nerve involvement yield a totally normal test, i.e. nerve conduction studies and electromyography are entirely normal in patients with SFN.

Therefore, specialized testing has been developed to evaluate the function of autonomic and unmyelinated sensory fibers. Although most institutions have developed different protocols for testing of small fibers, SFN confirmatory tests can grossly be divided into two subtypes: (A) tests to evaluate somatic (sensory) small fibers; and (B) tests to evaluate the function of autonomic fibers.

\section{A - Tests for selective evaluation of somatic small fibers}

\section{Thermoregulatory sweat test}

The thermoregulatory sweat test consists of dusting the body surface with an indicator powder (alizarin
Table. Causes of small fiber neuropathy.

\begin{tabular}{|c|}
\hline Metabolic and/or nutritional \\
\hline $\begin{array}{l}\text { Diabetes mellitus, metabolic syndrome/glucose intolerance, } \\
\text { insulin neuritis }{ }^{11,17}\end{array}$ \\
\hline Chronic renal insufficiency ${ }^{18}$ \\
\hline Thiamine or B12 deficiency (myeloneuropathy spectrum) $)^{11,19}$ \\
\hline Hyper- or hypothyroidism ${ }^{11,20}$ \\
\hline Hyperlipidemia ${ }^{21}$ \\
\hline Infectious \\
\hline Leprosy²2 \\
\hline $\mathrm{HIV}^{23}, \mathrm{HTLV}^{24}$ \\
\hline Hepatitis $C^{25}$ \\
\hline Chagas disease ${ }^{26}$ \\
\hline Amyloidosis \\
\hline Systemic ${ }^{27}$ \\
\hline Familial (familial amyloid polyneuropathy) ${ }^{28}$ \\
\hline Autoimmune \\
\hline Celiac disease ${ }^{15}$ \\
\hline Sjögren's disease $e^{29}$ \\
\hline Inflammatory bowel disease ${ }^{13,14}$ \\
\hline Systemic lupus erythematosus ${ }^{30}$ \\
\hline Rheumatoid arthritis ${ }^{31}$ \\
\hline Sarcoidosis ${ }^{32}$ \\
\hline Guillain-Barré syndrome variants ${ }^{33}$ \\
\hline Drugs \\
\hline $\begin{array}{l}\text { Extensive list, chronic metronidazole, statins, anti-TNF } \\
\text { inhibitor, bortezomib }\end{array}$ \\
\hline Toxins \\
\hline Thallium, arsenic, alcohol ${ }^{35,36}$ \\
\hline Vaccinations ${ }^{37}$ \\
\hline Hereditary forms \\
\hline $\begin{array}{l}\text { Hereditary sensory and autonomic neuropathy, Fabry disease, } \\
\text { sodium channelopathies, Wilson's disease, Pompe disease, Fragile } \\
\text { X-associated tremor/ataxia syndrome, Ehlers-Danlos syndrome }\end{array}$ \\
\hline Neurodegenerative \\
\hline Parkinson's disease, Amyotrophic lateral sclerosis ${ }^{42,43}$ \\
\hline Cryptogenic \\
\hline
\end{tabular}

red or starch powder over the body surface with an aqueous iodine solution - Minor's test). The powder turns from orange to purple or dark purple, to almost black when wet. The patient is kept in an enclosed cabinet with a moderately hot and humid environment $\left(45^{\circ}-50^{\circ} \mathrm{C}\right.$ air temperature with $35-40 \%$ relative humidity). The mean skin temperature is monitored and kept between $38.5^{\circ}$ and $39.5^{\circ} \mathrm{C}$ (overhead infrared heaters). The oral temperature must rise at least $1^{\circ} \mathrm{C}$ or to $38^{\circ} \mathrm{C}$ (whichever is higher). Maximal sweating is achieved in 30-65 minutes. Digital photographs of the sweating and non-sweating areas are taken, and a computerized body image is generated. A software compares the sweat patterns with laboratory controls. In addition to evaluating peripheral small fibers, the test also evaluates preganglionic sympathetic fibers and central nervous system autonomic pathways ${ }^{45}$. This test is currently available in a few academic institutions in Brazil. 


\section{Quantitative sensory testing}

Quantitative sensory tests are psychophysiological tests (dependent on the patient's self-assessment and report) designed to evaluate the thresholds for detection of vibration, temperature (most commonly cold, but also warm) sensations and pain. Although they have been employed in several clinical trials (usually for both small- and large-fiber involvement), they have significant limitations: central loss cannot be differentiated from peripheral loss and feigned sensory loss cannot easily be differentiated ${ }^{46}$. Newer algorithms decrease the risk of feigned deficits and heat and heat-pain thresholds are better suited for small fiber assessment. This test is currently available in a few academic institutions in Brazil. A Brazilian version of a quantitative sensory testing device has also been validated ${ }^{47}$.

\section{Contact heat evoked potentials}

Contact heat evoked potentials are potentials that are generated by a device that provides rapid cycles of heat. Their amplitudes correlate with cutaneous nociceptive nerve fiber density ${ }^{48}$. A recent study in patients with Parkinson's disease revealed that contact heat evoked potential amplitudes could be modulated by dopamine levels (ON and OFF stages), suggesting that evaluation of small fibers may be affected by central factors when one uses this technique ${ }^{49}$ in contrast with a laser evoked potential study $^{50}$. Another study concluded that small fibers are affected in patients with meralgia paresthetica and neuropathic pain ${ }^{51}$. There is a strong correlation of contact heat evoked potential findings with the intra-epidermal nerve fiber density observed in skin biopsy. A recent study reported normative data for contact heat evoked potentials ${ }^{52}$. This study involved several different international peripheral nerve centers including one in Brazil (Federal Fluminense University, Rio de Janeiro). This method has the advantage of being noninvasive and does not induce burning lesions in the area where heat stimuli are applied, contrasting with the laser evoked potentials test. This test is currently available in very few institutions in Brazil.

\section{B - Tests for selective evaluation of autonomic small fibers}

\section{Quantitative sudomotor axonal reflex testing}

Quantitative sudomotor axon reflex testing evaluates postganglionic sudomotor function through iontophoresis induced with acetylcholine applied to the skin. Several complex devices have been developed to accomplish this task, including a recentlydesigned commercially-available machine, called QSweat ${ }^{53}$. In general, four sites are mapped, two distal and two proximal in the upper and lower extremities, allowing the evaluation of a distal-to-proximal neuropathy gradient involvement. Some authors have observed moderate test-retest reliability (at least for older versions of the quantitative sudomotor axon reflex test), suggesting limitations for longitudinal assessment of sudomotor function with quantitative sudomotor axon reflex testing ${ }^{54}$. This test is currently available in very few academic institutions in Brazil.

\section{Skin wrinkling test}

Skin wrinkling is mediated by sympathetic activity. The observation that amputated fingers maintain the ability to vasodilate while not wrinkling supports this premise. Recent studies have validated osmotic and EMLA-induced skin wrinkling $^{55,56}$. They revealed that an index of skin wrinkling from four fingers (all but the thumb) correlated with the fiber density in skin biopsies ${ }^{57}$. The great advantage is the low cost but the evaluation of skin wrinkling may be limited in hands with calluses or other labor-related issues. Although not very popular worldwide (despite the low cost), this test has been used in at least one institution (only for research purposes) in Brazil.

\section{Sympathetic skin responses}

Sympathetic skin responses are electrical potentials obtained in the skin by electrodes that are positioned on the palms and soles of the feet. Potentials are dependent on the changes in sudomotor activity, providing a measurement of sympathetic cholinergic activity ${ }^{58}$. Different stereotyped stimuli have been used to elicit sympathetic skin responses, such as inspiratory gasp, auditory stimuli (clapping of the hands) or electrical stimuli. The sympathetic skin response is mediated through long spinal cord descending pathways and is not affected by pure autonomic failure restricted to sympathetic adrenergic pathways. It can be absent in normal old individuals and, therefore, usually is not considered a very reliable test. However, since it can readily be performed with most electromyography equipment, it has been used as a screening tool for autonomic involvement in several centers. This test is probably the most-employed screening tool for autonomic involvement in Brazil.

\section{Heart rate response to deep breathing and Valsalva test (cardiovagal function tests)}

Due to their availability in several electromyography packages worldwide, the heart rate response to deep breathing and Valsalva ratio tests have frequently been used in several neurophysiology laboratories. The heart rate response to deep breathing is affected by several factors (hypocapnia, sympathetic activity, position of the individual, medication, obesity and depth of breathing) but age and rate of breathing are the two most important modulating factors. The $\mathrm{R}-\mathrm{R}$ variation is maximal at rates of five to six breaths per minute, so the patient is instructed to establish smooth breathing at this rate (usually following an oscillating bar) in 10-second intervals. Eight cycles are recorded, followed by a five-minute rest and repeated testing. The five largest consecutive responses are read, averaged and the heart rate range derived $^{59}$. The Valsalva ratio is established by asking the patient to maintain a column of mercury at $40 \mathrm{mmHg}$ for 15 seconds via a bugle with an air leak, to keep an open glottis. The Valsalva ratio is derived from the maximum heart rate generated by the Valsalva maneuver divided by the lowest heart rate within the 30-second period of peak heart rate ${ }^{60}$. In addition to diagnostic purposes, at least for diabetic neuropathies, these tests can have a prognostic value $^{57}$. Although very popular worldwide (due to the low cost), 
these tests are only used for research purposes in Brazil (they were not approved for standard routine medical testing).

\section{C - Tests for evaluation of somatic and/or autonomic small fibers}

\section{Skin biopsy}

Skin biopsies are increasingly being employed to evaluate small fiber function and this is the most important diagnostic test to evaluate small fibers in the USA and Europe (it is starting to become available in Brazil but with level A recommendation on European guidelines). Standard 3-mm dermatologic punch biopsies can be taken from any part of the body, but have been standardized for the distal lateral leg and thigh, to demonstrate a length-dependent pattern ${ }^{58}$. The morphometric evaluation of linear density of intra-epidermal nerve fibers should include normative values for different genders and ages, and this has been considered a very safe procedure with no serious side effects in 35,000 biopsies over 10 years ${ }^{61}$. New technical variants have evolved to evaluate autonomic function (sweat gland innervation) as well as PMP22 expression and alpha-synuclein deposits $^{62,63}$. Evaluation of older patients is less reliable due to higher dispersion/non-Gaussian distribution. Neuropathy could also be feigned by prior administration of agents that lead to denervation, such as capsaicin. Another drawback is that decreased intra-epidermal fiber density could be secondary to involvement of the distal portions of large sensory fibers, and not necessarily selective involvement of unmyelinated and thinly myelinated fibers, making the interpretation of the results of the skin biopsies more complicated. Although skin biopsy is considered a gold-standard test for the diagnosis of small fiber neuropathies in several recommendations from different societies (e.g. Lauria et al. 2010 ${ }^{61}$ ), an unequivocal clinical-histological correlation is still under discussion. It is currently available at very few academic institutions in Brazil and has been used to evaluate HIV-related neuropathy in a Brazilian study ${ }^{64}$.

\section{In vivo confocal microscopy}

The use of confocal microscopy has recently gained attention in the medical literature to evaluate small fiber function. The cornea is densely innervated by sensory and autonomic trigeminal fibers ( $\mathrm{C}$ and $\mathrm{A} \delta$ fibers) and corneal confocal microscopy has also emerged as a new diagnostic tool to evaluate small fiber neuropathy in several medical conditions. In patients with diabetes mellitus, several parameters of corneal confocal microscopy correlate with intra-epidermal nerve fiber density ${ }^{65}$. Very recently, normative data for corneal confocal microscopy from Brazil (Federal Fluminense University, Rio de Janeiro) have been reported ${ }^{66}$.

\section{Grading scale of certainty for the diagnosis of small fiber neuropathies}

There have been several attempts to develop scales for the diagnosis of SFN. A recent tool was designed that proposed to grade SFN according to clinical symptoms, signs and findings from validated examinations ${ }^{67,68}$. A diagnosis of 'possible' SFN is present for length-dependent symptoms and/or clinical signs of small-fiber damage. A diagnosis of 'probable' SFN is made by length-dependent symptoms, clinical signs of small-fiber damage, and normal sural nerve conduction studies. Finally, a diagnosis of 'definite' SFN is made by length-dependent symptoms, clinical signs of small-fiber damage, normal sural nerve conduction studies, altered intra-epidermal nerve fiber density at the ankle and/or abnormal quantitative sensory testing thermal thresholds at the foot. These criteria have been proposed for diabetic SFN, but can be applied to all patients with suspected SFN, irrespective of the associated disease or condition. Figure 1 details a flowchart that we have designed for the evaluation of patients with suspected SFN.

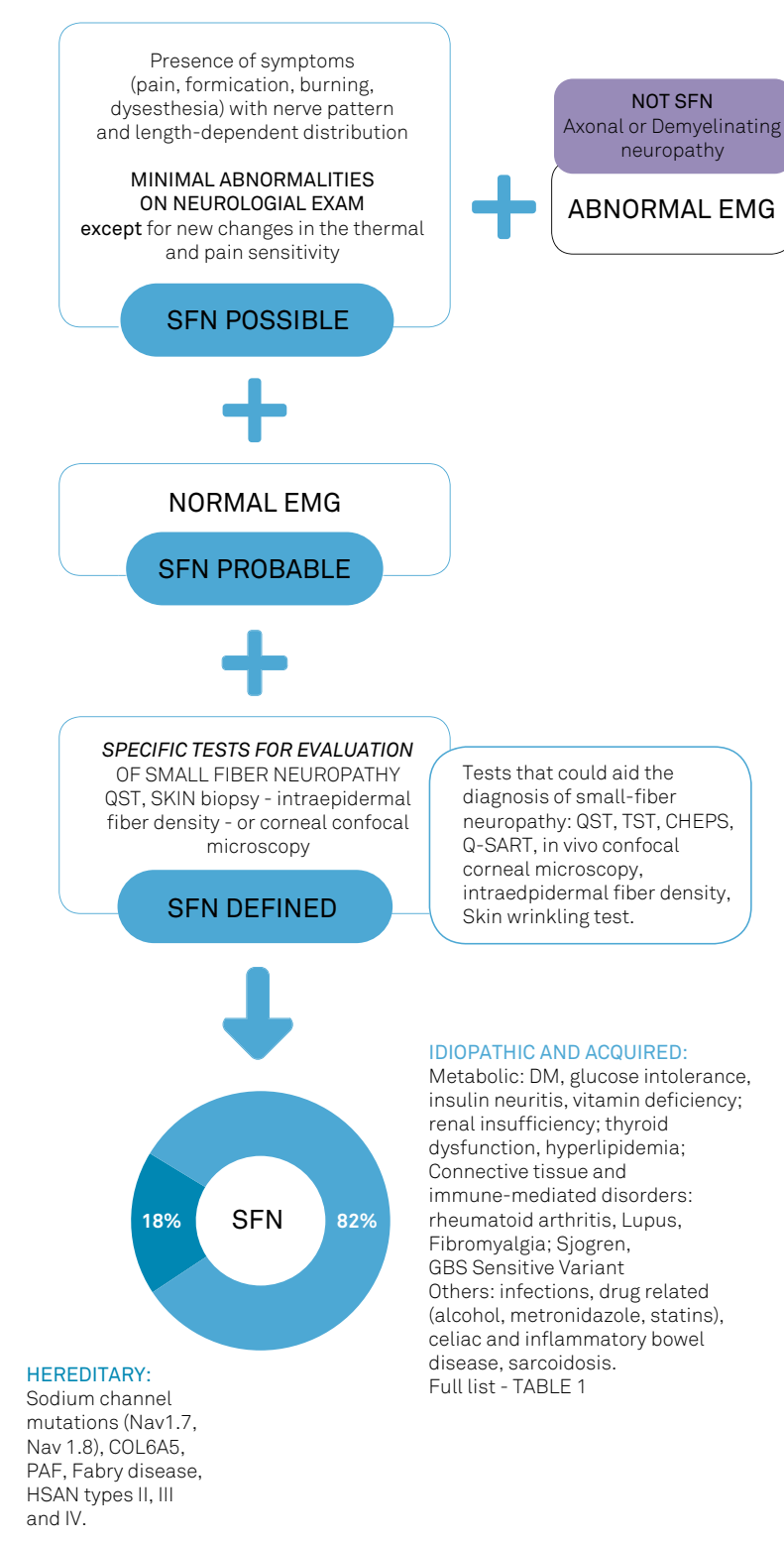

QST: quantitative sensory testing; CHEPS: contact heat evoke potentials; TST: thermoregulatory sweat test; Q-SART: quantitative sudomotor axonal reflex test. Figure. Schematic view of the evaluation of the patient with small fiber neuropathy (SFN) leading to disease classification as possible, probable and defined according to different test results. The lower part of the diagram depicts the most common forms of SFN. 


\section{Tests to confirm the etiology of small fiber neuropathies}

Whenever possible, investigation and testing should be based on disease history, clinical examination, past medical and family history. There is no evidence-based literature to establish which tests should initially be employed to evaluate the etiology of SFN. If no clue is provided by the clinical history, a reasonable (low cost) initial screening panel should include at least: fasting glucose (or, ideally, a glucose tolerance test and HgA1c), VDRL, TSH and serum vitamin B12 levels. Testing for total cholesterol levels, LDL, and triglycerides may also be relevant but are still controversial. A second step should include homocysteine and methylmalonic acid levels, rheumatoid factor, immunofixation electrophoresis, ANA, ACE levels, anti-endomysial antibodies (or antitransglutaminase), HIV, HTLV, and hepatitis B and C screening. Additional tests should be chosen according to gender, nutritional status and age. Lumbar puncture should be considered whenever an inflammatory, autoimmune or paraneoplastic disorder is suspected. In Brazil, due to the relatively high prevalence of leprosy in several regions, leprosy screening (or at least clinical consideration) in patients with SFN is mandatory. Also, it is important to consider the diagnosis of familial amyloid neuropathy, a condition that has been detected in some areas in Brazil.

\section{CONCLUSIONS}

SFN represents a controversial and heterogeneous group of disorders. The main characteristic is a disproportional repertoire of sensory neuropathic complaints in a patient with an almost entirely normal neurological examination and conventional electromyography testing. Although not necessarily entirely true for all cases, the current label of SFN may serve as an important aid for the diagnosis of peripheral neuropathy and avoid confusion (naming a patient with neuropathy and normal electrodiagnostic testing as "normal") generated by diverse neurophysiological sets of normal values within different laboratory tests.

\section{References}

1. Gondim FA, Barreira AA, Cruz MW, Cunha FMB, Freitas MRG, França Jr MC, Marques Jr W, Nascimento OJM, Bulle Oliveira AS, Pereira RC, Pupe C, Rotta FT, SchestaskyP. Definition and diagnosis of small fiber neuropathy (SFN): recommendations from the Brazilian Academy of Neurology. J Peripher Nerv Syst. 2017;22(3):292-3.

2. Berthold CH, Fraher JP, King RH, Rydmark M. Microscopic anatomy of the peripheral nervous system. In Dyck PJ, Thomas PK. Peripheral neuropathy. 4th ed. Philadelphia: Elsevier Sauders; 2005. Vol 1, p. 35-91.

3. King RH. Unmyelinated nerve fibers. In Dyck PJ, Thomas PK. Peripheral neuropathy. 4th ed. Philadelphia: Elsevier Sauders; 2005. Vol 1, p. 62-7.

4. Chan AC, Wilder-Smith EP. Small fiber neuropathy: getting bigger! Muscle Nerve. 2016 May;53(5):671-82. https://doi.org/10.1002/mus.25082

5. Ochoa J, Mair WG. The normal sural nerve in man. I. Ultrastructure and numbers of fibres and cells. Acta Neuropathol. 1969;13(3):197-216. https://doi.org/10.1007/BF00690642

6. Merkies IS, Faber CG, Lauria G. Advances in diagnostics and outcome measures in peripheral neuropathies. Neurosci Lett. 2015 Jun;596(596):3-13. https://doi.org/10.1016/j.neulet.2015.02.038

7. Stewart JD, Low PA, Fealey RD. Distal small fiber neuropathy: results of tests of sweating and autonomic cardiovascular reflexes. Muscle Nerve. 1992 Jun;15(6):661-5. https://doi.org/10.1002/mus.880150605

8. Pereira MP, Mühl S, Pogatzki-Zahn EM, Agelopoulos K, Ständer S. Intraepidermal nerve fiber density: diagnostic and therapeutic relevance in the management of chronic pruritus: a review. Dermatol Ther (Heidelb). 2016 Dec;6(4):509-17. https://doi.org/10.1007/s13555-016-0146-1

9. Brannagan TH 3rd, Hays AP, Chin SS, Sander HW, Chin RL, Magda P et al. Small-fiber neuropathy/neuronopathy associated with celiac disease: skin biopsy findings. Arch Neurol. 2005 Oct;62(10):1574-8. https://doi.org/10.1001/archneur.62.10.1574

10. Khoshnoodi MA, Truelove S, Burakgazi A, Hoke A, Mammen AL, Polydefkis M. Longitudinal Assessment of Small Fiber Neuropathy: Evidence of a Non-Length-Dependent Distal Axonopathy. JAMA Neurol. 2016 Jun;73(6):684-90. https://doi.org/10.1001/jamaneurol.2016.0057
11. Gibbons $\mathrm{CH}$. Small fiber neuropathies. In: Levin KH, editor. Peripheral nervous system disorders. Riverwoods: Wolters Kluwer Health; 2014. p. 1398-1412.

12. Peters MJ, Bakkers M, Merkies IS, Hoeijmakers JG, van Raak EP, Faber CG. Incidence and prevalence of small-fiber neuropathy: a survey in the Netherlands. Neurology. 2013 Oct;81(15):1356-60. https://doi.org/10.1212/WNL.0b013e3182a8236e PMID:23997150

13. Gondim FA, Brannagan TH 3rd, Sander HW, Chin RL, Latov N. Peripheral neuropathy in patients with inflammatory bowel disease. Brain. 2005 Apr;128(Pt 4):867-79. https://doi.org/10.1093/brain/awh429

14. Gondim FA, de Oliveira GR, Teles BC, Aquino PS, Brasil EF, Carvalho AM et al. Clinical and Electrodiagnostic Findings in Patients with Peripheral Neuropathy and Inflammatory Bowel Disease. Inflamm Bowel Dis. 2015 Sep;21(9):2123-9. https://doi.org/10.1097/MIB.0000000000000459

15. Thawani SP, Brannagan TH 3rd, Lebwohl B, Green PH, Ludvigsson JF. Risk of Neuropathy Among 28,232 Patients With Biopsy-Verified Celiac Disease. JAMA Neurol. 2015 Jul;72(7):806-11. https://doi.org/10.1001/jamaneurol.2015.0475

16. Pasnoor M, Nascimento OJ, Trivedi J, Wolfe Gl, Nations S, Herbelin L et al. North America and South America (NA-SA) neuropathy project. Int J Neurosci. 2013 Aug;123(8):563-7. https://doi.org/10.3109/00207454.2013.782026

17. Gibbons $\mathrm{CH}$, Freeman R. Treatment-induced diabetic neuropathy: a reversible painful autonomic neuropathy. Ann Neurol. 2010 Apr;67(4):534-41. https://doi.org/10.1002/ana.21952

18. Chao CC, Wu VC, Tan CH, Wang YM, Tseng MT, Wu PC et al. Skin denervation and its clinical significance in late-stage chronic kidney disease. Arch Neurol. 2011 Feb;68(2):200-6. https://doi.org/10.1001/archneurol.2010.372

19. Oliveira GR, Teles BC, Brasil EF, Souza MH, Furtado LE, de Castro-Costa CM et al. Peripheral neuropathy and neurological disorders in an unselected Brazilian population-based cohort of IBD patients. Inflamm Bowel Dis. 2008 Mar;14(3):389-95. https://doi.org/10.1002/ibd.20304 
20. Ørstavik K, Norheim I, Jørum E. Pain and small-fiber neuropathy in patients with hypothyroidism. Neurology. 2006 Sep;67(5):786-91. https://doi.org/10.1212/01.wnl.0000234035.13779.4a

21. McManis PG, Windebank AJ, Kiziltan M. Neuropathy associated with hyperlipidemia. Neurology. 1994 Nov;44(11):2185-6. https://doi.org/10.1212/WNL.44.11.2185

22. Nascimento OJ. Leprosy neuropathy: clinical presentations. Arq Neuropsiquiatr. 2013 Sep;71 9B:661-6. https://doi.org/10.1590/0004-282X20130146

23. Polydefkis M, Yiannoutsos CT, Cohen BA, Hollander H, Schifitto G, Clifford DB et al. Reduced intraepidermal nerve fiber density in HIV-associated sensory neuropathy. Neurology. 2002 Jan;58(1):1159. https://doi.org/10.1212/WNL.58.1.115

24. Nascimento OJ, Marques W Jr. Human T-cell leukemia virus (HTLV)associated neuropathy. Handb Clin Neurol. 2013;115:531-41. https://doi.org/10.1016/B978-0-444-52902-2.00030-8

25. Tembl JI, Ferrer JM, Sevilla MT, Lago A, Mayordomo F, Vilchez JJ. Neurologic complications associated with hepatitis C virus infection. Neurology. 1999 Sep;53(4):861-4. https://doi.org/10.1212/WNL.53.4.861

26. Nolano M, Provitera V, Manganelli F, Pagano A, Perretti A, Santoro L. Small fiber neuropathy in the chronic phase of Chagas disease: a case report. Clin Auton Res. 2013 Jun;23(3):149-53. https://doi.org/10.1007/s10286-013-0189-7

27. Kissel JT, Mendell JR. Neuropathies associated with monoclonal gammopathies. Neuromuscul Disord. 1996 Jan;6(1):3-18. https://doi.org/10.1016/0960-8966(95)00021-6

28. Conceição I, González-Duarte A, Obici L, Schmidt HH, Simoneau D, Ong ML et al. "Red-flag" symptom clusters in transthyretin familial amyloid polyneuropathy. J Peripher Nerv Syst. 2016 Mar;21(1):5-9. https://doi.org/10.1111/jns.12153

29. Indart S, Hugon J, Guillausseau PJ, Gilbert A, Dumurgier J, Paquet $\mathrm{C}$ et al. Impact of pain on cognitive functions in primary Sjögren syndrome with small fiber neuropathy: 10 cases and a literature review. Medicine (Baltimore). 2017 Apr;96(16):e6384. https://doi.org/10.1097/MD.0000000000006384

30. Gøransson LG, Tjensvoll AB, Herigstad A, Mellgren SI, Omdal R. Small-diameter nerve fiber neuropathy in systemic lupus erythematosus. Arch Neurol. 2006 Mar;63(3):401-4. https://doi.org/10.1001/archneur.63.3.401

31. Gøransson LG, Brun JG, Harboe E, Mellgren SI, Omdal R. Intraepidermal nerve fiber densities in chronic inflammatory autoimmune diseases. Arch Neurol. 2006 Oct;63(10):1410-3. https://doi.org/10.1001/archneur.63.10.1410

32. Bakkers M, Merkies IS, Lauria G, Devigili G, Penza P, Lombardi R et al. Intraepidermal nerve fiber density and its application in sarcoidosis. Neurology. 2009 Oct;73(14):1142-8. https://doi.org/10.1212/WNL.0b013e3181bacf05

33. Makonahalli R, Seneviratne J, Seneviratne U. Acute small fiber neuropathy following Mycoplasma infection: a rare variant of Guillain-Barré syndrome. J Clin Neuromuscul Dis. 2014 Jun;15(4):147-51. https://doi.org/10.1097/CND.0000000000000031

34. Zeng L, Alongkronrusmee D, van Rijn RM. An integrated perspective on diabetic, alcoholic, and drug-induced neuropathy, etiology, and treatment in the US. J Pain Res. 2017 Jan;10:219-28. https://doi.org/10.2147/JPR.S125987

35. Koike H, lijima M, Sugiura M, Mori K, Hattori N, Ito H et al. Alcoholic neuropathy is clinicopathologically distinct from thiamine-deficiency neuropathy. Ann Neurol. 2003 Jul;54(1):19-29. https://doi.org/10.1002/ana.10550

36. Latov N, Vo ML, Chin RL, Carey BT, Langsdorf JA, Feuer NT. Abnormal Nutritional Factors in Patients Evaluated at a Neuropathy Center. J Clin Neuromuscul Dis. 2016 Jun;17(4):212-4. https://doi.org/10.1097/CND.0000000000000128
37. Kafaie J, Kim M, Krause E. Small fiber neuropathy following vaccination. J Clin Neuromuscul Dis. 2016 Sep;18(1):37-40. https://doi.org/10.1097/CND.0000000000000130

38. Santiago S, Espinosa ML, Pérez-Conde MC, Merino M, Ferrer T. [Small fiber dysfunction in peripheral neuropathies]. Rev Neurol. 1999 Mar;28(6):543-54. Spanish.

39. Han C, Hoeijmakers JG, Liu S, Gerrits MM, te Morsche RH, Lauria G et al. Functional profiles of SCN9A variants in dorsal root ganglion neurons and superior cervical ganglion neurons correlate with autonomic symptoms in small fibre neuropathy. Brain. 2012 Sep;135(Pt 9):2613-28. https://doi.org/10.1093/brain/aws187

40. Samuelsson K, Kostulas K, Vrethem M, Rolfs A, Press R. Idiopathic small fiber neuropathy: phenotype, etiologies, and the search for fabry disease. J Clin Neurol. 2014 Apr;10(2):108-18. https://doi.org/10.3988/jcn.2014.10.2.108

41. Gondim FA, Araújo DF, Oliveira IS, Vale OC. Small fiber dysfunction in patients with Wilson's disease. Arq Neuropsiquiatr. 2014 Aug;72(8):592-5. https://doi.org/10.1590/0004-282X20140090

42. Cazzato D, Castori M, Lombardi R, Caravello F, Bella ED, Petrucci A et al. Small fiber neuropathy is a common feature of Ehlers-Danlos syndromes. Neurology. 2016 Jul;87(2):155-9. https://doi.org/10.1212/WNL.0000000000002847

43. de Araújo DF, de Melo Neto AP, Oliveira ÍS, Brito BS, de Araújo IT, Barros IS et al. Small (autonomic) and large fiber neuropathy in Parkinson disease and parkinsonism. BMC Neurol. 2016 Aug;16(1):139. https://doi.org/10.1186/s12883-016-0667-3

44. Weis J, Katona I, Müller-Newen G, Sommer C, Necula G, Hendrich C et al. Small-fiber neuropathy in patients with ALS. Neurology. 2011 Jun;76(23):2024-9. https://doi.org/10.1212/WNL.0b013e31821e553a

45. Davis MD, Genebriera J, Sandroni P, Fealey RD. Thermoregulatory sweat testing in patients with erythromelalgia. Arch Dermatol. 2006 Dec;142(12):1583-8. https://doi.org/10.1001/archderm.142.12.1583

46. Freeman R, Chase KP, Risk MR. Quantitative sensory testing cannot differentiate simulated sensory loss from sensory neuropathy. Neurology. 2003 Feb;60(3):465-70. https://doi.org/10.1212/WNL.60.3.465

47. Schestatsky P, Stefani LC, Sanches PR, Silva Júnior DP, Torres ILS, Dall-Agnol L et al. Validation of a Brazilian quantitative sensory testing (QST) device for the diagnosis of small fiber neuropathies. Arq Neuropsiquiatr. 2011;69(6):943-8. https://doi.org/10.1590/S0004-282X201100070001

48. Chao CC, Hsieh SC, Tseng MT, Chang YC, Hsieh ST. Patterns of contact heat evoked potentials (CHEP) in neuropathy with skin denervation: correlation of CHEP amplitude with intraepidermal nerve fiber density. Clin Neurophysiol. 2008 Mar;119(3):653-61. https://doi.org/10.1016/j.clinph.2007.11.043

49. Priebe JA, Kunz M, Morcinek C, Rieckmann P, Lautenbacher S. Electrophysiological assessment of nociception in patients with Parkinson's disease: A multi-methods approach. J Neurol Sci. 2016 Sep;368:59-69. https://doi.org/10.1016/j.jns.2016.06.058

50. Schestatsky P, Kumru H, Valls-Solé J, Valldeoriola F, Marti MJ, Tolosa E et al. Neurophysiologic study of central pain in patients with Parkinson disease. Neurology. 2007 Dec;69(23):2162-9. https://doi.org/10.1212/01.wnl.0000295669.12443.d3

51. Schestatsky P, Lladó-Carbó E, Casanova-Molla J, Alvarez-Blanco S, Valls-Solé J. Small fibre function in patients with meralgia paresthetica. Pain. 2008 Oct;139(2):342-8. https://doi.org/10.1016/j.pain.2008.05.001

52. Granovsky Y, Anand P, Nakae A, Nascimento O, Smith B, Sprecher E et al. Normative data for A $\delta$ contact heat evoked potentials in adult population: a multicenter study. Pain. 2016 May;157(5):1156-63. https://doi.org/10.1097/j.pain.0000000000000495

53. Sletten DM, Weigand SD, Low PA. Relationship of Q-sweat to quantitative sudomotor axon reflex test (QSART) volumes. Muscle Nerve. 2010 Feb;41(2):240-6. https://doi.org/10.1002/mus.21464 
54. Berger MJ, Kimpinski K. Test-retest reliability of quantitative sudomotor axon reflex testing. J Clin Neurophysiol. 2013 Jun;30(3):308-12. https://doi.org/10.1097/WNP.0b013e3182873254

55. Teoh HL, Chow A, Wilder-Smith EP. Skin wrinkling for diagnosing small fibre neuropathy: comparison with epidermal nerve density and sympathetic skin response. J Neurol Neurosurg Psychiatry. 2008 Jul;79(7):835-7. https://doi.org/10.1136/jnnp.2007.140947

56. Wilder-Smith EP. Stimulated skin wrinkling as an indicator of limb sympathetic function. Clin Neurophysiol. 2015 Jan;126(1):10-6. https://doi.org/10.1016/j.clinph.2014.08.007

57. Vetrugno R, Liguori R, Cortelli P, Montagna P. Sympathetic skin response: basic mechanisms and clinical applications. Clin Auton Res. 2003 Aug;13(4):256-70. https://doi.org/10.1007/s10286-003-0107-5

58. Low PA, Zimmerman BR, Dyck PJ. Comparison of distal sympathetic with vagal function in diabetic neuropathy. Muscle Nerve. 1986 Sep;9(7):592-6. https://doi.org/10.1002/mus.880090703

59. Low PA, Walsh JC, Huang CY, McLeod JG. The sympathetic nervous system in diabetic neuropathy. A clinical and pathological study. Brain. 1975 Sep;98(3):341-56. https://doi.org/10.1093/brain/98.3.341

60. May $\mathrm{O}$, Arildsen $\mathrm{H}$. Simple function tests for autonomic neuropathy have a higher predictive value on all-cause mortality in diabetes compared to 24-h heart rate variability.J Diabetes Complications. 2012 MayJun;26(3):246-50. https://doi.org/10.1016/j.jdiacomp.2012.03.004

61. Lauria G, Hsieh ST, Johansson O, Kennedy WR, Leger JM, Mellgren SI et al.; European Federation of Neurological Societies; Peripheral Nerve Society. European Federation of Neurological Societies/ Peripheral Nerve Society Guideline on the use of skin biopsy in the diagnosis of small fiber neuropathy. Report of a joint task force of the European Federation of Neurological Societies and the Peripheral Nerve Society. Eur J Neurol. 2010 Jul;17(7):903-12. https://doi.org/10.1111/j.1468-1331.2010.03023.x
62. Donadio V, Incensi A, Cortelli P, Giannoccaro MP, Jaber MA, Baruzzi A et al. Skin sympathetic fiber $\alpha$-synuclein deposits: a potential biomarker for pure autonomic failure. Neurology. 2013 Feb;80(8):725-32. https://doi.org/10.1212/WNL.0b013e3182825127

63. Li J, Bai Y, Ghandour K, Qin P, Grandis M, Trostinskaia A et al. Skin biopsies in myelin-related neuropathies: bringing molecular pathology to the bedside. Brain. 2005 May;128(Pt 5):1168-77. https://doi.org/10.1093/brain/awh483

64. Moura L, Oliveira AS, Zanoteli E, Cardoso R, Schmidt B, Gabbai AA. [Normal pattern of intraepidermal nerve fibers in 30 healthy volunteers with PGP 9.5]. Arq Neuropsiquiatr. $2004 \mathrm{Jun} ; 62\left(2^{\mathrm{a}}\right): 271-5$. Portuguese. https://doi.org/10.1590/S0004-282X2004000200015

65. Chen X, Graham J, Dabbah MA, Petropoulos IN, Ponirakis G, Asghar $O$ et al. Small nerve fiber quantification in the diagnosis of diabetic sensorimotor polyneuropathy: comparing corneal confocal microscopy with intraepidermal nerve fiber density. Diabetes Care. 2015 Jun;38(6):1138-44. https://doi.org/10.2337/dc14-2422 PMID:25795415

66. Dieckmann G, Pupe C, Nascimento OJ. Corneal confocal microscopy in a healthy Brazilian sample. Arq Neuropsiquiatr. 2016 Jan;74(1):10-7. https://doi.org/10.1590/0004-282X20150178

67. Malik RA, Veves A, Tesfaye S, Smith G, Cameron N, Zochodne D et al.; Toronto Consensus Panel on Diabetic Neuropathy. Small fibre neuropathy: role in the diagnosis of diabetic sensorimotor polyneuropathy. Diabetes Metab Res Rev. 2011 Oct;27(7):678-84. https://doi.org/10.1002/dmrr.1222

68. Tesfaye S, Boulton AJ, Dyck PJ, Freeman R, Horowitz M, Kempler P et al.; Toronto Diabetic Neuropathy Expert Group. Diabetic neuropathies: update on definitions, diagnostic criteria, estimation of severity, and treatments. Diabetes Care. 2010 Oct;33(10):2285-93. https://doi.org/10.2337/dc10-1303 